\title{
Dietary Effects of Desmodium (Desmodium adscendens) Leaves on the Reproductive Indices in African Catfish (Clarias gariepinus) Broodstock
}

\author{
Israel Opeyemi Oke ${ }^{1, *}{ }^{-1}$, Adekunle Ayokanmi Dada ${ }^{1}$, Olayemi Razaq Saliu ${ }^{1}$, Esther \\ Bosede Kuyoro $^{1}$
}

${ }^{1}$ Department of Fisheries and Aquaculture Technology, Federal University of Technology, P.M.B. 704, Akure, Ondo State, Nigeria.

\section{Article History}

Received August 17, 2019

Accepted November 20, 2019

First Online November 25, 2019

\section{Corresponding Author}

Tel.: +2348077890454

E-mail: oke_israel@yahoo.com

\section{Keywords}

Broodstock

Desmodium adscendens

Egg quality

Milt quality

\begin{abstract}
The effects of sweetheart plant (Desmodium adscendens) leaf powder on the reproductive indices of Clarias gariepinus was investigated in this study. 30 Male $C$. gariepinus (mean weight $325.7 \pm 7.50 \mathrm{~g}$ ) and 30 female $C$. gariepinus (mean weight $330.97 \pm 2.31 \mathrm{~g}$ ) were used for the experiment. Five diets with a crude protein of $40 \%$ were formulated with inclusion level of $0,0.5,1.0,1.5,2.0 \mathrm{~g}$ of Desmodium adscendens leaf powder per $100 \mathrm{~g}$ of basal feed designated as D1, D2, D3, D4, and D5 respectively. The fish were stocked in 20 concrete tanks $(2 \mathrm{~m} \times 2 \mathrm{~m} \times 1.5 \mathrm{~m})$ at 3 fish/tank and water level maintained at $1 \mathrm{~m}$ throughout. Male and female fish were stocked separately. The fish were fed at $3 \%$ body weight twice between 0800 and 1700 hours daily for 56 days. Male $C$. gariepinus broodstock fed $1.5 \mathrm{~g}$ of Desmodium adscendens leaf powder per $100 \mathrm{~g}$ of basal feed had significantly higher $(P<0.05)$ sperm counts, percentage motility and milt volume. There was a significant difference $(P<0.05)$ in the weight of ovaries of female fish. The inclusion level of $1.5 \mathrm{~g}$ and $2.0 \mathrm{~g}$ of $D$. adscendens powder in $100 \mathrm{~g}$ of basal feed improved the pro-fertility of male and female brood stock respectively.
\end{abstract}

\section{Introduction}

Aquaculture is the rational rearing of fish and other aquatic organisms in an enclosed water body (Nash, 2011). In Nigeria, fish farming is the most practiced form of aquaculture. Some of the challenges faced by fish farmers are quality feeds, quality fish seeds, and environmental factors. Fish reproduction under controlled conditions requires the obtaining of high quality sperm and egg from male and female fish brood stock respectively to produce the highest possible numbers of good quality seeds (Adeparusi et al., 2010). Other factors that affect fish seeds quality includes different strains, genetics, nutrition, the content of feed and activities of modern agriculture which have introduced several substances such as organic matter, chemical fertilizer, and insecticides into the water used for cultured medium (Conyurt and Akhan, 2008).

The need for high quality fish seed has necessitated the involvement of research in fertility enhancement to meet the growing demand for fish seeds (Dada, 2012). Medicinal plants are being investigated, evaluated and developed into drugs with little or no side effects (Oyedemi et al., 2018). The use of medicinal plants as fertility enhancer in aquaculture has been receiving some attention due to shifting attention from synthetic drugs to natural plants products (Dada and Ebhodaghe, 2011). Biological studies have supported claims that natural plants have medicinal values and due to the 
antioxidants in them, they have the tendency of enhancing fertility either directly or indirectly (Ashamu et al., 2010; Oluyemi et al., 2007). Fertility enhancing properties of some plants in Nigeria has been ascertained. Some of these plants include Garcinia kola (Dada and Ajilore, 2009), Kigelia Africana (Adeparusi et al., 2010), Tetracarpidium conophorum (Adekunle and Aguda, 2015), Sesamum indicum and Croton zambesicus (Dada and Adeparusi, 2012).

Desmodium adscendens is a vine that grows well on the West Coast of Africa and in the Amazon rainforest of Peru. Native people use $D$. adscendens as juice or tea for medicinal purpose in different parts of the world (Muanda et al., 2011). The leaves of this plant are used to treat leucorrhoea, body aches, pains, ovarian inflammations, excessive urination, gonorrhoea, and diarrhoeas (Muanda et al., 2010). Its positive effect against hepatic infection was also verified in vivo (Heard, 1994). In African traditional medicine, D. adscendens is extensively used to treat asthma and other diseases associated with smooth muscle contraction (Gyamfi et al., 1999). The extracts of $D$. adscendens leaves has been found to exhibit interesting antioxidant properties and reactive oxygen species scavenging activity. The presence of natural antioxidants in $D$. adscendens justified its use in folk medicine (Muanda et al., 2010).

C. gariepinus is widely cultivated in Nigeria due to its ability to consume supplementary feed, good conversion of feed to flesh, resistance to disease, ability to reproduce in captivity, fast growth rate and tolerance to a wide range of environmental conditions (Ayinla, 1997). Many hatcheries in Nigeria are functional at low capacity producing only a total of some 30 million fingerlings per year (Dada and Fagbenro, 2008). The rapid growth of the fish farming sector is a reason to focus on improved broodstocks for an increase in fish seeds production and control fertility in broodstocks. Therefore, the objective of this research is to examine the effectiveness of Desmodium adscences leaves powder as a fertility agent in fish seed production.

\section{Material and Methods}

\section{Formulation of Experimental diets}

Fresh leaves of Desmodium adscendens were collected from the oil palm plantation of the Federal University of Technology, Akure, Ondo-state. Identification and authentication were done at the Department of Crop, Soil and Pest Management, Federal University of Technology, Akure. The leaves were washed, air-dried at room temperature and pulverized into flour. Amounts of 0 (control), 0.5, 1.00, 1.5, $2.0 \mathrm{~g}$ of D. adscendens powder per $100 \mathrm{~g}$ of feed were taken and mixed with a basal feed ( $40 \%$ Crude protein), containing fish meal, soybean meal, yellow maize, blood meal, vegetable oil, fish oil, vitamin premix and binder (starch). All dietary ingredients were milled. The ingredients were thoroughly mixed in a Hobart A-2007 (Hobart Ltd, London, UK) pelleting and mixing machine to obtain a homogenous mash. The resultant mash was pressed without steam through a mixer with $6 \mathrm{~mm}$ die attached to the Hobart pelleting machine. The pellets were dried at ambient temperature $\left(27-30^{\circ} \mathrm{C}\right)$ and kept in a cool dry place (Table 1).

\section{Experimental Procedure}

Ten concrete tanks $\left(1 \times 2 \times 1.5 \mathrm{~m}^{3}\right)$ at the Department of Fisheries and Aquaculture Technology Fish Farm, Federal University of Technology, Akure. Five dietary

Table 1. Ingredients composition $(\mathrm{kg})$ and proximate composition (\%DM) basal diet

\begin{tabular}{|c|c|c|c|c|c|}
\hline \multirow[b]{2}{*}{ Ingredients } & \multicolumn{5}{|c|}{ Treatments } \\
\hline & D1 & $\mathrm{D} 2$ & D3 & D4 & D5 \\
\hline Fishmeal (65\% cp) & 25 & 25 & 25 & 25 & 25 \\
\hline Yellow maize & 100 & 100 & 100 & 100 & 100 \\
\hline Soybean meal(45\% cp) & 35 & 35 & 35 & 35 & 35 \\
\hline Blood meal ( $85 \% \mathrm{cp})$ & 10 & 10 & 10 & 10 & 10 \\
\hline Fish oil & 6 & 6 & 6 & 6 & 6 \\
\hline Vegetable oil & 4.0 & 3.5 & 3.0 & 2.5 & 2.0 \\
\hline Vitamin premix* & 3 & 3 & 3 & 3 & 3 \\
\hline Starch & 20 & 20 & 20 & 20 & 20 \\
\hline D. adscendens (g/kg) feed & 0 & 0.5 & 1.0 & 1.5 & 2.0 \\
\hline \multicolumn{6}{|l|}{ Proximate Composition (\%) } \\
\hline Crude protein & 39.75 & 40.01 & 40.12 & 40.23 & 40.35 \\
\hline Crude lipid & 14.11 & 13.09 & 13.64 & 13.59 & 14.26 \\
\hline Crude fibre & 3.30 & 2.90 & 2.12 & 2.20 & 3.61 \\
\hline Ash & 14.60 & 15.53 & 17.90 & 15.18 & 19.05 \\
\hline NFE & 22.42 & 23.80 & 19.73 & 23.63 & 18.40 \\
\hline
\end{tabular}

*Vitamin premix: An $\mathrm{Hi}-\mathrm{mix}^{\circledR}$ product

NFE: Nitrogen free extracts $(((M C+C P+A C+E E+C F)-100)$ 
treatments (D1, D2, D3, D4, and D5) were set-up in duplicate at a stocking density of six fish per tank. Fish were fed at $3 \%$ body weight twice daily (0800 and 1700 hours). All fish were weighed fortnightly and feeding rates were adjusted consequently. The experiment lasted for 56 days. At the end of??? experiment period the following reproductive indices were determined ovaries weight (g), Egg number/fish, Egg number/Kg Body weight, Egg diameter for females and Testes weight (g), Milt count(105spzml), milt volume (ml), Motility (\%), Motility duration (sec) for males. Gonadosomatic index for females and males was also determined.

Gonado-somatic index $=($ gonad weight $(\mathrm{g}) /$ total body weight (g)) x 100 (Abbas et al., 2008).

Water quality parameters of experiment 1 varied as follows: dissolved oxygen, 6.07-6.94 mg/l; temperature, $26.35-28.19^{\circ} \mathrm{C} ; \mathrm{pH}, 6.71-7.53$. Water quality results during experiment II were as follows: temperature, 26.00-26.04 ${ }^{0} \mathrm{C}$; dissolved oxygen 4.20-4.40 mg/l; $\mathrm{pH}$, 7.20-7.50. Physio-chemical properties of the water used in experiment I and II are within the recommended range for C. gariepinus (Bhatnangar et al., 2010, APHA, 2002, Ekubo and Abowei, 2002).

\section{Statistical Analysis}

The effect of $D$. adscendens on the fertility of $C$. gariepinus brood stock was analysed using one-way analysis of variance (ANOVA) and significant difference among treatments were compared using Duncan multiple range test.

\section{Results and Discussion}

Experiment I- Reproductive performance of Female C. gariepinus Fed dietary supplementation of $D$. adscendens

Data on growth performance, ovaries weight, egg numbers are presented in Table 2 . There was a significant difference $(P<0.05)$ in the weight gain of fish fed the five prepared diets. There was no significant difference $(P>0.05)$ in the egg number, egg diameter, gonado-somatic index of fish fed the different diets. Yeldan and Avsar (2000) reported that Gonado- somatic Index (GSI) is used in order to examine the spawning period because its value is directly related to the development and quality of the gonad. There was no significant difference in the GSI across the treatments. The GSI recorded in this study is higher than those reported by Ekanem et al. (2017) using S. jamaicenesis and G. kola on female African catfish. The result is also higher than the range reported by Eyo et al, (2014) for female catfish feed with two different commercial diets. There was no significant difference in the GSI across treatments. Though there was no significant difference $(P<0.05)$ in the egg number per fish. The increase in egg number per fish obtained in this study could be as a result of the presence of bioflavonoids, xanthone and carotenoids in D. adscendences leaves (MacManus et al., 1993; Asante-Poku et al., 1988). Astaxanthin supplementation in cultured salmon and red sea bream increased ovary development, fertilization, hatching and larval growth (Torrissen and Christiansen, 1995). Adesanya et al. (2007) reported that bioflavonoids and xanthone are potent antioxidants capable of increasing the production of oestrogen, a key hormone in production and maturation of eggs in the ovaries.

Experiment II- Reproductive performance of Male C. gariepinus Fed dietary supplementation of $D$. adscendens

The average initial weight of male $C$. gariepinus used for the experiment was $325.74 \pm 7.50 \mathrm{~g}$. Results on growth performance in Table 3 show that weight gain was highest in fish fed D5 $\left(20 \mathrm{gkg}^{-1}\right.$ of $D$. adscendens powder) compared to other diets. There was no significant difference $(P>0.05)$ in the lengths of fish fed different experimental diets. There was a significant difference $(P<0.05)$ in the milt count, motility, milt

Table 2. Female sexual parameters of $C$. gariepinus brood stock as affected by dietary supplementation of $D$. adscendences

\begin{tabular}{|c|c|c|c|c|c|}
\hline \multirow[t]{2}{*}{ Parameter } & \multicolumn{5}{|c|}{ Treatments } \\
\hline & D1 & D2 & D3 & D4 & D5 \\
\hline Initial Fish weight (g) & $327.6 \pm 2.3^{a}$ & $332.9 \pm 2.6^{a}$ & $329.9 \pm 2.6^{a}$ & $334.1 \pm 3.10^{a}$ & $330.3 \pm 1.1^{a}$ \\
\hline Final Fish Weight (g) & $511.7 \pm 6.5^{b}$ & $509.6 \pm 18.2^{b}$ & $499.3 \pm 5.5^{a}$ & $534.7 \pm 16.3^{b}$ & $492.3 \pm 0.5^{a}$ \\
\hline Weight gain (g) & $183.9 \pm 4.3^{a}$ & $176.8 \pm 20.6^{b}$ & $169.4 \pm 2.9^{a}$ & $200.6 \pm 13.2^{b}$ & $162.1 \pm 0.6^{a}$ \\
\hline Ovaries Weight (g) & $94.7 \pm 0.26^{a}$ & $90.8 \pm 5.62^{\mathrm{a}}$ & $100.2 \pm 1.5^{b}$ & $97.0 \pm 1.8^{\mathrm{a}}$ & $100.2 \pm 3.6^{b}$ \\
\hline Egg Number/Fish $\left(\times 10^{3}\right)$ & $47.80 \pm 2.7$ & $48.30 \pm 8.4$ & $51.28 \pm 1.9$ & $56.00 \pm 8.6$ & $56.6 \pm 7.7$ \\
\hline Egg Number/Kg (x103) & 259.83 & 273.25 & 302.69 & 279.19 & 349.12 \\
\hline \multicolumn{6}{|l|}{$\mathrm{BW}^{* *}$} \\
\hline Egg Diameter & $1.50 \pm 0.00$ & $1.50 \pm 0.00$ & $1.55 \pm 0.05$ & $1.60 \pm 0.00$ & $1.60 \pm 0.00$ \\
\hline GSI & $18.70 \pm 1.77$ & $17.31 \pm 0.91$ & $20.0 \pm 1.23$ & $17.12 \pm 2.01$ & $17.93 \pm 1.19$ \\
\hline
\end{tabular}

Means in the same row with the same superscript are not significantly different $(P>0.05)$

$\mathrm{GSI}=$ Gonado - somatic index

**BW= Body Weight 
Table 3. Male sexual parameters of $C$. gariepinus brood stock as affected by dietary supplementation of $D$. adscendences

\begin{tabular}{|c|c|c|c|c|c|}
\hline \multirow[t]{2}{*}{ Parameter } & \multicolumn{5}{|c|}{ Treatments } \\
\hline & D1 & D2 & D3 & D4 & D5 \\
\hline Fish weight (g) & $452.8 \pm 53.2^{\mathrm{a}}$ & $488.4 \pm 5.55^{\mathrm{ab}}$ & $562.35 \pm 2.15^{c}$ & $500.00 \pm 30.25^{\mathrm{ab}}$ & $576.80 \pm 31.40^{c}$ \\
\hline Length of fish $(\mathrm{cm})$ & $40.40 \pm 1.00^{a}$ & $40.80 \pm 1.10^{\mathrm{a}}$ & $43.05 \pm 0.15^{a}$ & $41.20 \pm 1.40^{\mathrm{a}}$ & $43.10 \pm 0.00^{\mathrm{a}}$ \\
\hline Milt count (x105spzml) & $1.60 \pm 0.13^{a}$ & $1.75 \pm 0.05^{\mathrm{ab}}$ & $1.97 \pm 0.14^{\mathrm{ab}}$ & $1.91 \pm 0.04^{\mathrm{ab}}$ & $2.29 \pm 0.33^{c}$ \\
\hline Milt volume (ml) & $0.50 \pm 0.10^{\mathrm{a}}$ & $0.40 \pm 0.00^{a}$ & $0.75 \pm 0.05^{b}$ & $0.65 \pm 0.05^{b}$ & $0.75 \pm 0.05^{b}$ \\
\hline Motility (\%) & $55.95 \pm 1.65^{a}$ & $56.50 \pm 2.70^{a}$ & $63.65 \pm 4.45^{\mathrm{ab}}$ & $78.80 \pm 2.35^{c}$ & $72.75 \pm 0.95^{b c}$ \\
\hline Motility duration (sec) & $2.76 \pm 0.40^{\mathrm{a}}$ & $2.59 \pm 0.51^{\mathrm{a}}$ & $2.85 \pm 0.44^{\mathrm{ab}}$ & $3.46 \pm 0.05^{b}$ & $3.33 \pm 0.80^{\mathrm{bc}}$ \\
\hline GSI & $0.65 \pm 0.00$ & $0.57 \pm 0.10$ & $0.64 \pm 0.03$ & $0.65 \pm 0.00$ & $0.42 \pm 0.02$ \\
\hline
\end{tabular}

Means in the same row with the same superscript are not significantly different $(P>0.05)$

GSI= Gonado - somatic index

volume, weight of testes and gonado-somatic index of experimental fish after feeding trial for 56 days. Reproductive indices of the male $C$. gariepinus breeders in this experiment shows that inclusion of $D$. adscendences leaf powder had effects on the testes weight, milt motility, gonado-somatic index, and milt volume. The GSI recorded in this study is lower than thatrecoeded in the works of Ekanem et al. (2017) Results of works done by Dada et al. (2011) and Igoli et al. (2005), also reported an increase in the reproductive indices of male $C$. gariepinus broodstocks using Mucuna puriensi as a pro-fertility agent in their study. The length of time and intensity of spermatozoa motility, percentage motile sperm, and sperm density are all parameters that have been measured in an attempt to assess sperm quality in human, mammals, and fish (Billard and Cosson, 1992). Motility of the spermatozoan is the most commonly used indicator of milt quality since high motility is a prerequisite for fertilization and correlates strongly with fertilization success (Rurangwa et al., 2001). Percentage motility recorded in this study is similar to result of Dada and Fagbohun, (2018) using Date palm seed powder on $C$. gariepinus male bloodstock. There was significant difference in the percentage motility of sperm in the experimental fish across different treatment. The highest percentage motility was recorded in fish fed diet containing $15 \mathrm{gkg}^{-1}$ $D$. adscendences powder. There was no significant difference $(P<0.05)$ in the milt count of the male $C$. gariepinus broodstock fed the control and D5 diets. Male $C$. gariepinus broodstock fed diet 4 had the best gonado-somatic index value, motility duration, and motility. This reveals that the best inclusion level of $D$. adscendences is at $15 \mathrm{gkg}^{-1}$.

\section{Conclusion}

In conclusion, the inclusion of Desmodium adscendences leaves powder at $1.5 \mathrm{~g} / 100 \mathrm{~g}$ in the diet of male Clarias gariepinus broodstock and $2.0 \mathrm{~g} / 100 \mathrm{~g}$ in the diet of female Clarias gariepinus brood stock will improve the gamete quality of both female and male. This implies that Desmodium adscendences leaves have pro-fertility properties which could be a future prospect in the production of quality and adequate fish seeds.

\section{Acknowledgements}

The authors wish to thank the Department of Fisheries and Aquaculture Technology, Federal University of Technology, Akure for the use of their Teaching and Research farm and laboratory.

\section{References}

Adesanya, O.A., Oluyemi, K.A., Olusori, D.A., Omotuyi, I.O., Okwuonu, C.U., Ukwenya, O.V. and Adesanya, A.A. (2007). Micromorphometric and stereological effects of ethanolic extracts of Garcinia cambogia seeds on the testes and epididymides of adult Wistar rats. The Internet Journal of Alternative Medicine, 5, 1-9.

Adjanohoun, E.J. (1988). "Contribution to ethnobotanical and floristic studies in the People's Republic of Congo," Traditional Medicine and Pharmacopoeia Supplement, 3 , p. 428.

Asante-Poku, S., Sasakibara, J. and Addy, M.E. (1988). Alkaloids of Desmodium adscendens. Ghana Medical Journal 22 : 111-115.

Ashamu, E.A., Salawu, E.O., Oyewo, O.O., Alhassan, A.W., Alamu, O.A. and Adegoke, A.A. (2010) Efficacy of vitamin $C$ and ethanolic extract of Sesamum indicum in promoting fertility in male Wistar rats. Journal of Human Reproductive Science 3(1), 11-14

Billard, R. and Cosson, M.P. (1992). Some problems related to the assessment of sperm motility in freshwater fish. Journal of Experimental Zoology 261:122-131.

Bozkurt, Y., Secer, S., Bukan, N., Akcay, E. and Tehin, N. (2006). Relationship between body condition, physiological and biochemical parameters in brown trout. (Salmon trutta fario) sperm. Pakistan. Journal of Biological Sciences 9(5):940-944.

Carillo, M., Sanuy, S., Prat, F., Creda, J., Ramos, J., Mananos, E. and Bromage, N. (1995). Sea Bass (Dicentrachus labrax L). In: Brood stock Management and Egg and Larval Quality, (eds: Bromage N. and Roberts J.), Blackwell Science, Osmead, Oxford. 424 pp.

Dada, A.A. and Adeparusi, E.O. (2012). Dietary effects of two medicinal plants (Sesamum indicum) and (Croton zambesicum) on the reproductive indices in female 
African catfish (Clarias gariepinus) broodstock. Egyptian Journal of Aquatic Research 1: 1-5.

Dada, A.A. and Ajilore, V.O. (2009). Use of ethanol extracts of Garcinia Kola as fertility enhancer in female catfish Clarias gariepinus broodstock. International Journal of Fisheries and Aquaculture, 1(1):1-5.

Dada, A.A. and Ebhodaghe, B.E. (2011). Effect of Garcina kola seed meal on egg quality of the African catfish (Clarias gariepinus) (Burchell) broodstock. Cameroon Journal of Experimental Biology 7 (1):

Dada, A.A. and Fagbenro, O.A. (2008). Catfish fingerlings production in Nigeria. Proceedings of the $4^{\text {th }}$ Annual Conference of School of Agriculture and Agricultural Technology, Federal University of Technology, Akure. pp. $107-110$

Dada, A. A. and Fagbohun, A. E. (2018). Effects of Dietary Supplementation of Date palm (Phoenix dactylifera L.) Seed on Milt Quality of African Catfish (Clarias gariepinus) Broodstocks. The Journal of Agricultural Sciences. 13(2):153-161

Ekanem, S.B., Eyo, V.O. and Okon, E.E. (2017). The effects of Brazilian tea (Stachytarpheta jamaicensis) and Bitter kola (Garcinia kola) seed meal on the growth and gonad development of the African catfish Clarias gariepinus (Burchell, 1822). Ege Journal of Fisheries and Aquatic Sciences, 34(2): 179-185. doi:10.12714/egejfas.2017.34.2.09

Eyo, V. O., Ekanem, A. P., and Ufon-ima, U. J. (2014). A comparative study of the gonado-somatic index (GSI) and gonad gross morphology of African Catfish (Clarias gariepinus) fed Unical Aqua feed and Coppens Commercial feed. Croatian Journal of Fisheries, 72: 63 69.

Francis, O.M., Akinlolu, A.A. and Kehinde, O.A. (2013). Assessment of bitter leaf (Vernonia amygdalina) as fertility enhancer in the giant African Catfish (Heterobranchus bidorsalis) bloodstock. Academia Journal of Biotechnology 1(2):036-040

Gyamfi, M.A., Yonamine, M. and Aniya, Y. (1999). “Free-radical scavenging action of medicinal herbs from Ghana:
Thonningia sanguinea on experimentally-induced liver injuries" General Pharmacology, 32(6), pp. 661-667.

Heard, O. (1994). Contribution of the study of Desmodium adscendens: chemistry and pharmacology, Ph.D. Dissertation, University of Tours, France.

MacManus, O.B., Harris, G.H., Giangiacomo, K.M., Feigebaum, J.P., Reubem, J.P., Addy, M.E., Burka, J.F., Kaczorowski, G.J. and Garcia, M.L. (1993). An Activator of CalciumDependent Potassium channel isolated from a medicinal herb. Biochemical Journal, 32: 6128-6133.

Nash, C.E. (2011). The history of Aquaculture. John Willey and sons ISBN 978-0-8138-216,324. 236pp

Oluyemi, K.A., Jimoh, O.R., Josiah, S.J., Olamide, A.A., Omotuyi, O.I. and Oyesola, T.O. (2007) Effects of crude Ethanolic Extracts of Garcinia Cambogia on the Reproductive System of Male Wister Rats (Rattus Novergicus). African Journal of Biotechnology, 6(10): 1236-1238.

Oyedemi, B.O., Oyedemi, S.O., Chibuzor, J.V., Ijeh, I.I., Coopoosamy, R.M. and Aiyegoro, A.O. (2018). Pharmacological Evaluation of Selected Medicinal Plants Used in the Management of Oral and Skin Infections in Ebem-Ohafia District, Abia State, Nigeria. The Scientific World Journal 2018:1-16

Rurangwa, E., Volckaert, F.A., Huyskens, G., Kime, D.E. and Ollevier, E. (2001). Quality control of refrigerated and cryopreserved semen using computer-assisted sperm analysis (CASA), viable staining and standard fertilization in African catfish (Clarias gariepinus). Theriogenology, 55: 751-767. DOI: http://dx.doi.org/10.1016/s0093$691 \times(01) 00441-1$

Sule, O.D. and Adikwu, I.A. (2004) Effect of broodstock size on egg and larval size and survival of larvae of the African catfish, Clarias gariepinus under laboratory conditions. Journal of Aquatic Science 19 (1) 1-4.

Torrissen, O.J. and Christiansen, R. (1995). Requirements for carotenoids in fish diets. Journal of Applied Ichthyology, 11: 225-230.

Yeldan, H. and Avsar, D. A. (2000) Preliminary study on the reproduction of the rabbit fish Siganus rivulatus (Forsskal. 1775) in the North eastern Mediterranean. Turkish Journal of Zoology 24:173-182 